\title{
Submerged Vegetation and Water Quality Degeneration From Serious Flooding in Liangzi Lake, China
}

\author{
Ligong Wang, Yuqin Han, Haihao Yu, Shufeng Fan and Chunhua Liu* \\ The National Field Station of Freshwater Ecosystem of Liangzi Lake, College of Life Science, Wuhan University, Wuhan, China
}

In shallow lake ecosystems, flooding is a key disturbance factor of aquatic vegetation. Aquatic plants, especially submerged plants, play key roles in water ecosystems. Liangzi Lake experienced severe flooding in July 2010, and the elevated water levels lasted for 3 months. In this study, 10 transects with 120 monitoring points were set up for monthly monitoring during the 3-year period, encompassing the period before and after the flooding (2009-2011). The numbers, biomass, and diversity of the submerged plants, as well as the physical and chemical characteristics of the lake water, were surveyed. There were 12 species belonging to 7 families and 7 genera in Liangzi Lake. Eleven of the

OPEN ACCESS

Edited by:

Te Cao,

Chinese Academy of Sciences,

China

Reviewed by:

Wei Xing,

Chinese Academy of Sciences,

China

Hui Fu,

Hunan Agricultural University, China

*Correspondence:

Chunhua Liu

liuchh@163.com

Specialty section: This article was submitted to Functional Plant Ecology, a section of the journal

Frontiers in Plant Science

Received: 29 March 2019 Accepted: 29 October 2019 Published: 25 November 2019

Citation:

Wang L, Han Y, Yu H, Fan S and Liu C (2019) Submerged Vegetation and Water Quality Degeneration From Serious Flooding in Liangzi Lake, China.

Front. Plant Sci. 10:1504. doi: 10.3389/fp/s.2019.01504 submerged plant species were found in 2009, but, after the flood, that number decreased to five in 2011. The total biomass differed significantly over the three years $(P<0.05)$, with the largest biomass in 2009 and smallest in 2011. In 2009 and 2010, Potamogeton maackianus was the dominant species, but its dominant position weakened in 2011. After the flood, water transparency decreased, and the water depth, turbidity, total nitrogen, and total phosphorus increased. A redundancy analysis between the submerged plants and environmental factors found that the water transparency, turbidity, and water depth were the key environmental factors affecting the plants. These results suggest that the long-lasting severe flooding of Liangzi Lake in 2010 led to the degradation of both the submerged plant community and water quality.

Keywords: flooding, submerged vegetation, dominant species, water quality, diversity

\section{INTRODUCTION}

Submerged macrophyte vegetation plays a central role in the functioning of shallow lake ecosystems (Coops and Doef, 1996; Jeppesen et al., 1997; Meerhoff et al., 2003). It can provide feeding and spawning habitats for fish, provide sanctuary for zooplankton, and generally help improve the biodiversity and stability of lake ecosystems (Jeppesen et al., 1998; Wetzel, 2001; Heikkinen et al., 2009; Tamire and Mengistou, 2013; Yu et al., 2016). Among lakes, the factors influencing the submerged macrophyte distribution, diversity, and abundance include light availability (Middelboe and Markager, 1997; Phillips et al., 2016; Zhang et al., 2016; Verhofstad et al., 2017), water temperature (Scheffer et al., 1992; Short et al., 2016), nutrient enrichment (Sand-Jensen et al., 2008), bottom substrate (Andersson, 2001), herbivory (Marklund et al., 2002; Sponberg and Lodge, 2005), and the water level (Wilcox and Meeker, 1991). In shallow lake ecosystems, water level fluctuations are the main factor affecting the biomass and spatial distribution of aquatic plants and are an important ecological factor affecting their growth and reproduction (Gafny and Gasith, 1999; 
Strand and Weisner, 2001; Ishii and Kadono, 2004; Deegan et al., 2007; Schneider et al., 2018).

Flood is one of the important factors leading to fluctuation of water levels (Wantzen et al., 2008). In addition to a rise in the water level, the surface runoff caused by floods carries large amounts of potentially labile nitrogen and phosphorus into the lake, and the original endogenous nutrients used by aquatic plants are also released into the water (Carpenter, 2008; Keitel et al., 2016). Floods also resuspend the sediment, increasing the concentrations of suspended solid particles, nitrogen, and phosphorus in the water (Newman and Reddy, 1992; Tong et al., 2017). The phosphorus released by the resuspension of precipitates is 20-30 times higher than when they are undisturbed (Søndergaard et al., 1992). In addition, floods also restrict the availability of oxygen, inhibiting the growth of emergent and floating-leaved plants (Drew, 1997; Deegan et al., 2007; Lemke et al., 2014) and the germination of some species in the seed bank (Casanova and Brock, 2000; Johansson and Nilsson, 2002; Hölzel and Otte, 2004; Cui et al., 2017), thereby reducing the diversity of aquatic plant species (Jeppesen et al., 2015). Correspondingly, aquatic animal habitat and food sources also disappear, reducing species diversity, and thus the entire ecosystem becomes very vulnerable (Junk and Robertson, 1997; Dorn and Cook, 2015). In addition, climate change manifested through increasing temperatures and more variable precipitations impacted water quality, biodiversity, and ecological status of the world's lakes (Solheim et al., 2010; O'Reilly et al., 2015). Climate change is predicted to lead to earlier, stronger, and more frequent flooding (Fowler and Hennessy, 1995; Trenberth, 2011; Cai et al., 2015; Lehmann et al., 2015). For example, floods have become more frequent in the central United States (Hirsch and Archfield, 2015), and global warming has been linked to a substantial increase in flood risk in most countries in Central and Western Europe (Alfieri et al., 2018). The high frequency of future floods may have a more serious impact on water ecosystems (Watts et al., 2015; Castello and Macedo, 2016).

Flooding is a key disturbance factor of aquatic vegetation composition and community diversity in floodplain lakes (Tockner et al., 2000; Maltchik et al., 2005; Van Geest et al., 2005; Chaparro et al., 2014). The growth of emergent floating-leaved plants is not limited by low light penetration in the lake (Qiu et al., 2001a). Spate floods affected small to intermediate-sized submerged plant species, and long-term inundating floods affected tall submerged plant species (Bornette and Puijalon, 2011). The effects of water levels on submerged plants by simulating water level fluctuations for individual plants have been studied in depth (Armstrong et al., 1994; Vartapetian and Jackson, 1997; Vermaat et al., 2000; Lenssen et al., 2004; Wang et al., 2016a). For example, water depths greater than 3 meters severely reduced the survival of Vallisneria natans (Han et al., 2018). Potamogeton maackianus disappeared at an average depth of 6 meters in Erhai Lake (Fu et al., 2018a). Myriophyllum spicatum, Ceratophyllum demersum, and Potamogeton malaianus were more tolerant of deep water and flood intensity than P.maackianus and Hydrilla verticillata, as indicated by their larger biomass, plant height, stem tensile properties, and root anchorage strength (Zhu et al., 2012; Ye et al., 2018). The response of submerged plants to floods is species specific. Therefore, flooding with extreme water levels may cause shifts towards a macrophyte-dominated state (Coops et al., 2003).

In recent decades, floods have become more frequent in the middle reaches of the Yangtze River in China, and the rise in water levels has been greater than before (Li et al., 2015; Wang and Yuan, 2018). Lake Liangzi is located in the middle and lower reaches of the Yangtze River. From 2007 to 2016, two major floods occurred in Lake Liangzi, one in 2010 and one in 2016 (Xu et al., 2018). Ten transects with 120 monitoring points were set up for monthly monitoring during the 3-year period between 2009 and 2011 in order to compare the submerged vegetation and water characters before and after the flood in 2010. Specifically, we analyzed the relationship between submerged aquatic communities and water quality. Finally, we evaluate the consequences of flood regulation on the dominant submerged species.

\section{MATERIALS AND METHODS}

\section{Study Area and Flood}

Liangzi Lake $\left(30^{\circ} 04^{\prime} 55^{\prime \prime}-30^{\circ} 20^{\prime} 26^{\prime \prime} \mathrm{N}, 114^{\circ} 31^{\prime} 19^{\prime \prime}-114^{\circ} 42^{\prime} 52^{\prime \prime}\right.$ E) is located south of the Yangtze River in the southeast of Hubei Province, China. It is a typical grass-type lake, a type common in East China, with high vegetation coverage. The lake covers an area of $304.3 \mathrm{~km}^{2}$ and has a water storage capacity of about $14 \times 10^{8}$ tons.

The Liangzi Lake Basin suffered heavy rain, and Liangzi Lake was seriously flooded in July 2010, with the water level rapidly rising from $4.25 \mathrm{~m}$ to $6.2 \mathrm{~m}$. In addition, the high water levels continued for three months. The survey was conducted for monthly monitoring from January 2009 to December 2011. Monitoring plots were established in three regions of Liangzi Lake (named as Qianjiangdahu Lake, Manjianghu Lake, and Gaotanghu Lake) (Figure 1). Altogether, there were ten transects, with 120 monitoring points for the sampling set up at 400-meter intervals (Figure 1).

\section{Collection of Plant Samples and Water Parameter Measurements}

During each survey, submerged plant samples were collected on-site using a boat positioned by GPS (GARMIN eTrex Summit; Garmin, Inc., Olathe, KS, USA) navigation. At each monitoring site, the submerged plants were randomly sampled twice with a Peterson's mud filter $(0.2 \mathrm{~m} \times 0.3 \mathrm{~m})$. The collected samples were packed in plastic bags $(0.03 \mathrm{~L})$ and brought to the National Field Station for Freshwater Ecosystem at Liangzi Lake (hereinafter referred to as the Liangzi Lake National Station). The plants from the monitoring sites were first classified, the number of each species was counted, and they were then drained of surface water and weighed using an electronic scale $(0.01 \mathrm{~g})$ to obtain the wet weight. Some plant samples were dried at $80^{\circ} \mathrm{C}$ for $72 \mathrm{~h}$ and were then weighed to obtain dry-weight biomass, which was later converted to a submerged plant dry weight per unit area $\left(1 \mathrm{~m}^{2}\right)$.

Water parameters were monitored at the time of the submerged plant sampling. The water $\mathrm{pH}$, dissolved oxygen, and temperature were measured using a Pro Plus water quality monitor (YSI Inc., Yellow Springs, OH, USA); the water turbidity 


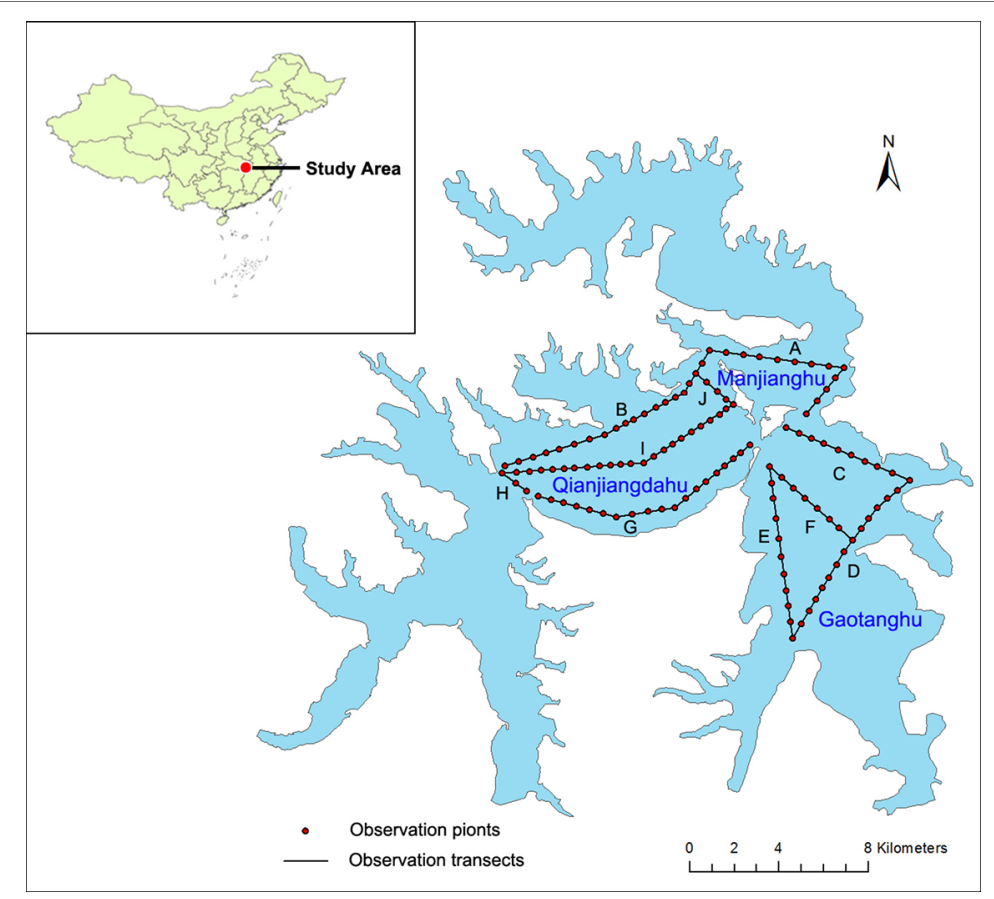

FIGURE 1 | Map of Liangzi lake showing sampling sites observation points. Ten transects: A. B. C. D. E. F. G. H. I. J.

was measured in nephelometric turbidity units (NTUs) using a HACH 2100P turbidity meter (HACH Co., Loveland, CO, USA); and the water depth and transparency were measured by Secchi depth monitoring. A Plexiglass water sampler was used to collect water samples; ten sites were sampled once a month from 2009 to 2011, and these were returned to the instrument room of the Liangzi Lake National Station where the total phosphorus and total nitrogen were determined with HACH IL500P and IL500N analyzers (HACH Co., USA). We thus had a total of 4,320 samples (3 years $\times 12$ months $\times 120$ sites), 360 total phosphorus, and total nitrogen samples ( 3 years $\times 12$ months $\times 10$ sites).

\section{Data Analysis}

The submerged plant diversity index was analyzed using the Shannon index formula:

$$
\mathrm{H}=-\sum(\mathrm{Pi})\left(\log _{2} \mathrm{Pi}\right)(\mathrm{MaGuarran}, 1988) .
$$

Only six submerged species were common in Liangiz Lake. Thus, the dominance analysis and redundancy analysis (RDA) were analyzed with the data for these six species. The dominance of the submerged plant species was calculated with the equation:

Dominance $=[($ relative frequency + relative weight $) / 2] \times 100 \%$ (Chen, 1980).

The data analyses were conducted using SPSS 22.0 software. To ensure that all data met the normal distribution requirements, data that were not normally distributed underwent a logarithmic transformation, but, to the data that were not normally distributed, non-parametric statistics were applied. We conducted a Kruskal-Wallis test to determine the differences in the water quality. A one-way ANOVA with Duncan's $(P<0.05)$ test for post hoc comparison was used to analyze the differences in species number, total biomass per area, total biomass of dominant species among 2009, 2010, and 2011, or during the same month over different years. A redundancy analysis (RDA) based on the biomass was conducted for the major water environmental factors affecting the submerged plant communities using Canoco for Windows 5.0 software.

\section{RESULTS}

\section{Species Number, Total Biomass and Diversity Index}

Twelve submerged plant species were monitored in Liangzi Lake from 2009 to 2011, which belonged to seven genera in seven families (Table 1). There was a significant change in the number of submerged plant species over the three years (Figure 2A), the number of species in 2009 being significantly higher than that in 2010 and 2011 (Figure 2A). A comparison of the number of species before and after flooding found no significant differences from March to July in 2009 and 2010, while the number present from August to December in 2009 was significantly higher than that in 2010 (Figure 2C). There were significant differences in the number of submerged plants with each month within the three years (Figure 2C).

There were significant differences in total biomass over the three years $(F=504.227, P<0.001$, the largest biomass identified 
TABLE 1 | Submerged plant species in Lake Liangzi.

\begin{tabular}{ll}
\hline Family & Species \\
\hline Characeae & Chara vulgaris \\
Ceratophyllaceae & Ceratophyllum demersum \\
Haloragaceae & M. spicatum \\
Hydrocharitaceae & H. verticillata \\
& Elodea nuttallii \\
Lentibulariaceae & Vallisneria spiralis \\
Najadaceae & Utricularia aurea \\
& Najas marina \\
Potamogetonaceae & N.minor \\
& Potamogeton crispus \\
& P. maackianus A. Bennett \\
& P.malaianus
\end{tabular}

in 2009 and the smallest in 2011 (Figures 2B, D). According to monthly data, the three years also had significant differences in the total biomass during each month (All $P<0.05$ ). The total biomass of the submerged plants differed significantly from each other in February, April, June, July, and August (Figure 2D). In January, March, and May, the total biomass of the submerged plants in 2009 showed no significant difference to that in 2010, whereas both them were significantly higher than in 2011 (Figure 2D).

Flooding decreased the Shannon diversity index (Figure 3). The Shannon index was highest in November 2009, while only one species was found in September, October, and December 2011, resulting in the lowest diversity index (Figure 3).

\section{Changes in the Dominant Species}

In the three years sampled, the dominance of $P$. maackianus was above $60 \%$, while the dominance was less significant among $C$. demersum, M. spicatum, and P. crispus. P. maackianus was the dominant species during whole year both in 2009 and 2010. However, the dominant species was P. crispus in March, April, May, November, and December of 2011, and only P. maackianus was present from June to October 2011 (Figure 4).

\section{Water Environmental Parameters}

There were significant difference in water depth $\left(\chi^{2}=871.013, P<\right.$ $0.001)$, transparency $\left(\chi^{2}=1667.673, P<0.001\right)$, turbidity $\left(\chi^{2}=\right.$ 1649.164, $P<0.001)$, dissolved oxygen $\left(\chi^{2}=218.637, P<0.001\right)$, $\mathrm{pH}\left(\chi^{2}=804.817, P<0.001\right)$, total nitrogen $\left(\chi^{2}=1165.63, P<\right.$
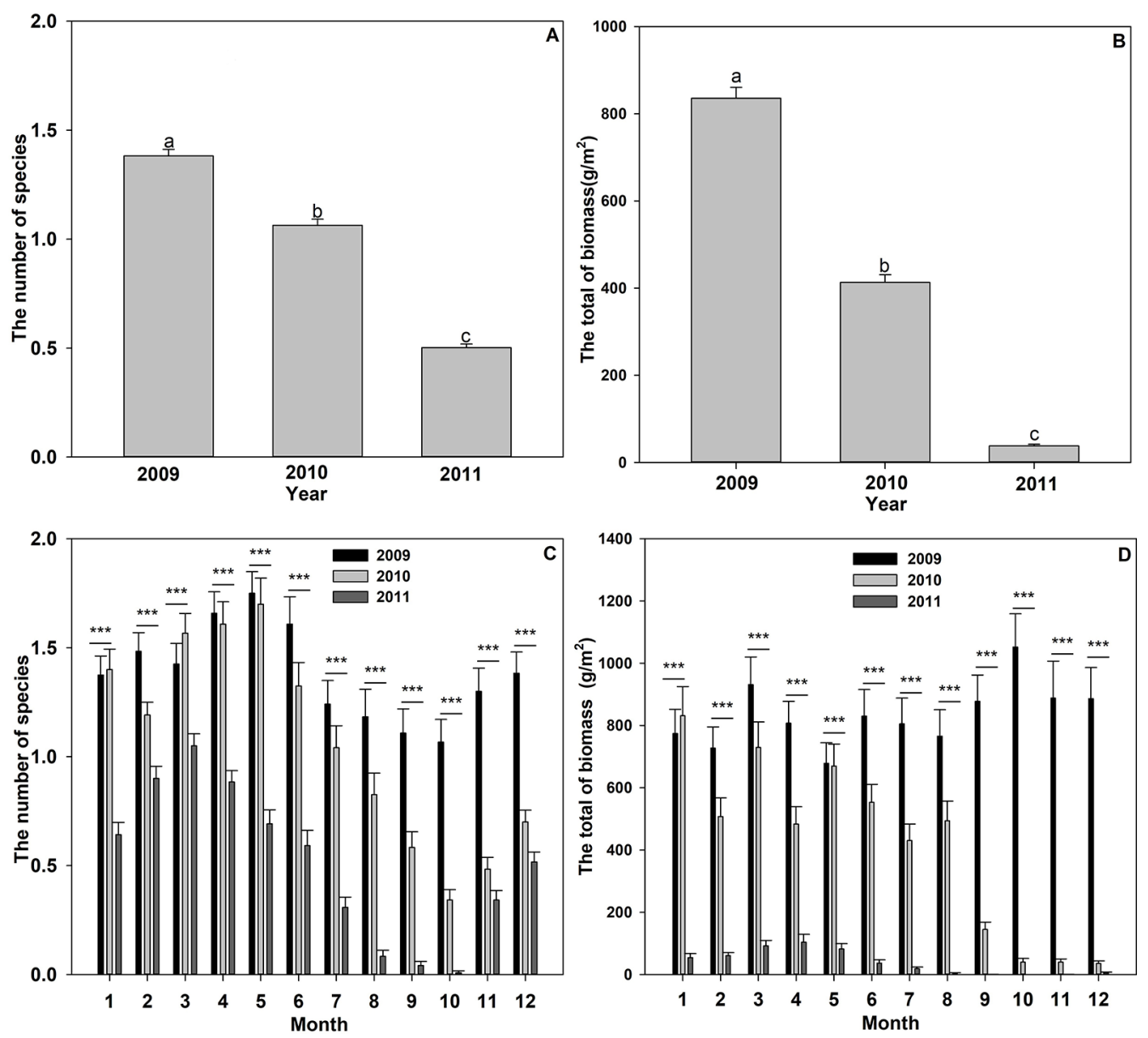

FIGURE 2 | Submerged species number $(\mathbf{A}, \mathbf{C})$ and the total biomass (B, D) in different years or different months. Values shown are means \pm S.E. Bars with different lowercase letters above are significantly different. Significant differences: ${ }^{\star \star \star} P<0.001$. 


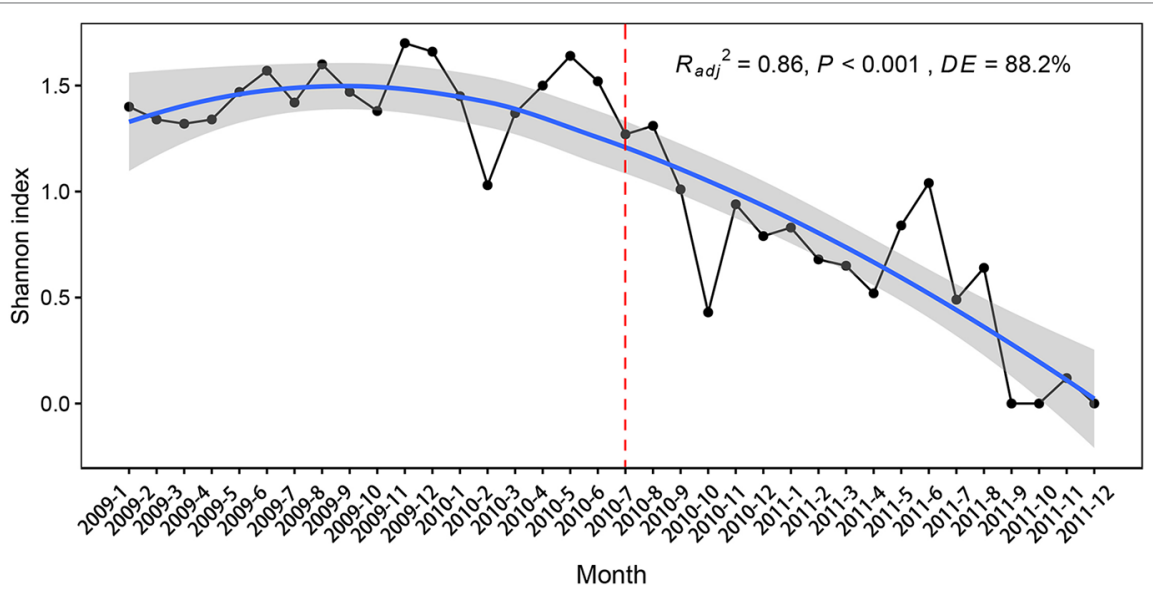

FIGURE 3 | The Shannon diversity species index of the submerged plants in 2009, 2010, and 2011.

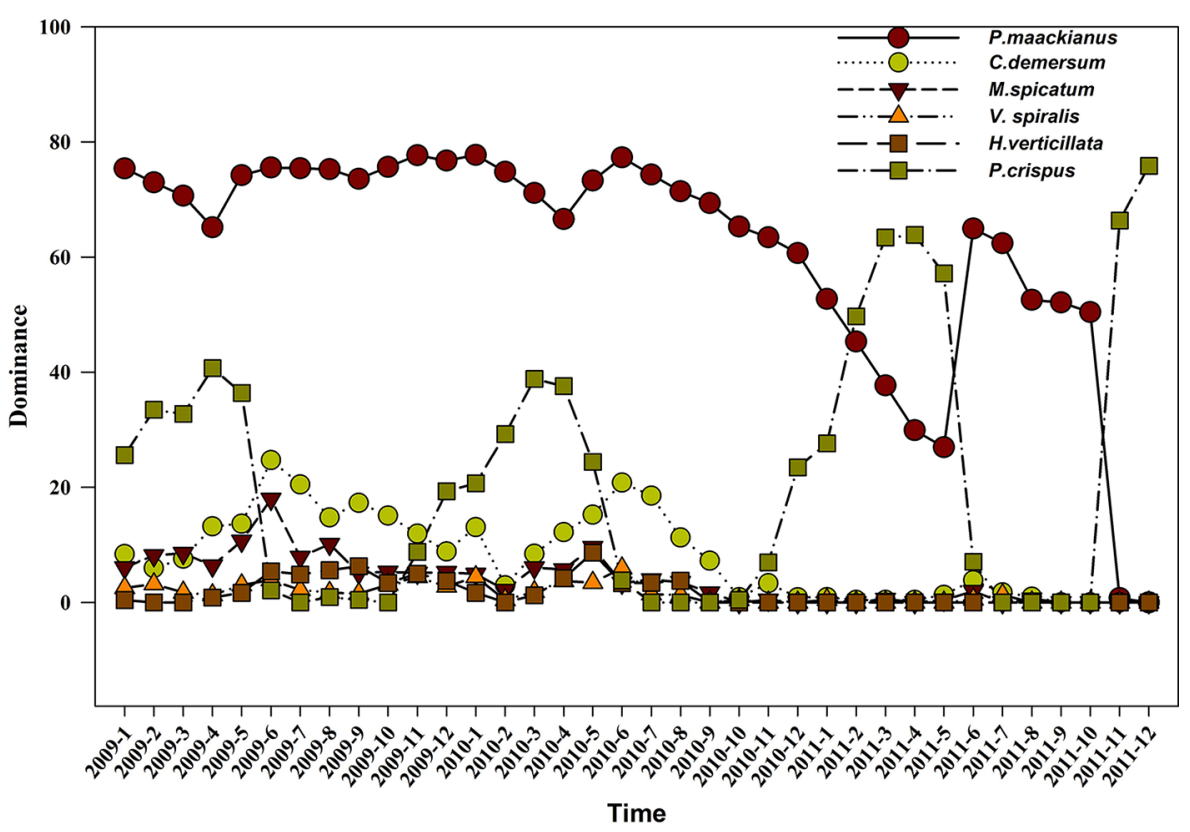

FIGURE 4 | The species dominance of the submerged plants in 2009, 2010, and 2011.

$0.001)$, and total phosphorus $\left(\chi^{2}=1704.382 P<0.001\right)$ over the three years, There was no significant difference in temperature $\left(\chi^{2}=2.4722, P=0.291\right)$.

The mean water depth of Lake Liangzi from January to October was greater in 2010 than in 2009 and 2011 (Figure 5A). On the other hand, water transparency was significantly lower in 2011 than that in 2009 and 2010, and the maximum transparency was found in August 2009 (Figure 5B). Water turbidity was significantly higher in 2011 than that in 2009 and 2010, reaching its highest value in March 2011 (Figure 5C). The highest water temperature values were reached in August, with an average maximum temperature of $34^{\circ} \mathrm{C}$, and lowest values were present in January, when the average minimum temperature was $3^{\circ} \mathrm{C}$ (Figure 5D). In contrast to the temperature, dissolved oxygen had an inverse trend, decreasing in the summer and increasing in the winter (Figure 5E). The lowest dissolved oxygen concentration values were present in July, with a mean of $6.34 \pm 0.793 \mathrm{mg} \cdot \mathrm{L}^{-1}$ (Figure 5E). The $\mathrm{pH}$ was significantly higher in 2011 than in 2009 (Figure 5F). Total nitrogen $(\mathrm{TN})$ was lower in $2009\left(0.310 \pm 0.01 \mathrm{mg} \cdot \mathrm{L}^{-1}\right)$ than in $2010\left(0.411 \pm 0.011 \mathrm{mg} \cdot \mathrm{L}^{-1}\right)$ and $2011\left(0.429 \pm 0.109 \mathrm{mg} \cdot \mathrm{L}^{-1}\right)$. (Figure 5G). Total phosphorus (TP) fluctuated slightly in 2009, whereas it fluctuated widely in 2010 and 2011 (Figure 5H). The mean value was $0.007 \pm 0.0005 \mathrm{mg} \cdot \mathrm{L}^{-1}$ in 2009 , and it was significantly less than in $2010\left(0.020 \pm 0.001 \mathrm{mg} \cdot \mathrm{L}^{-1}\right)$ and 2011 $\left(0.020 \pm 0.0008 \mathrm{mg} \cdot \mathrm{L}^{-1}\right)($ Figure 5H$)$. 

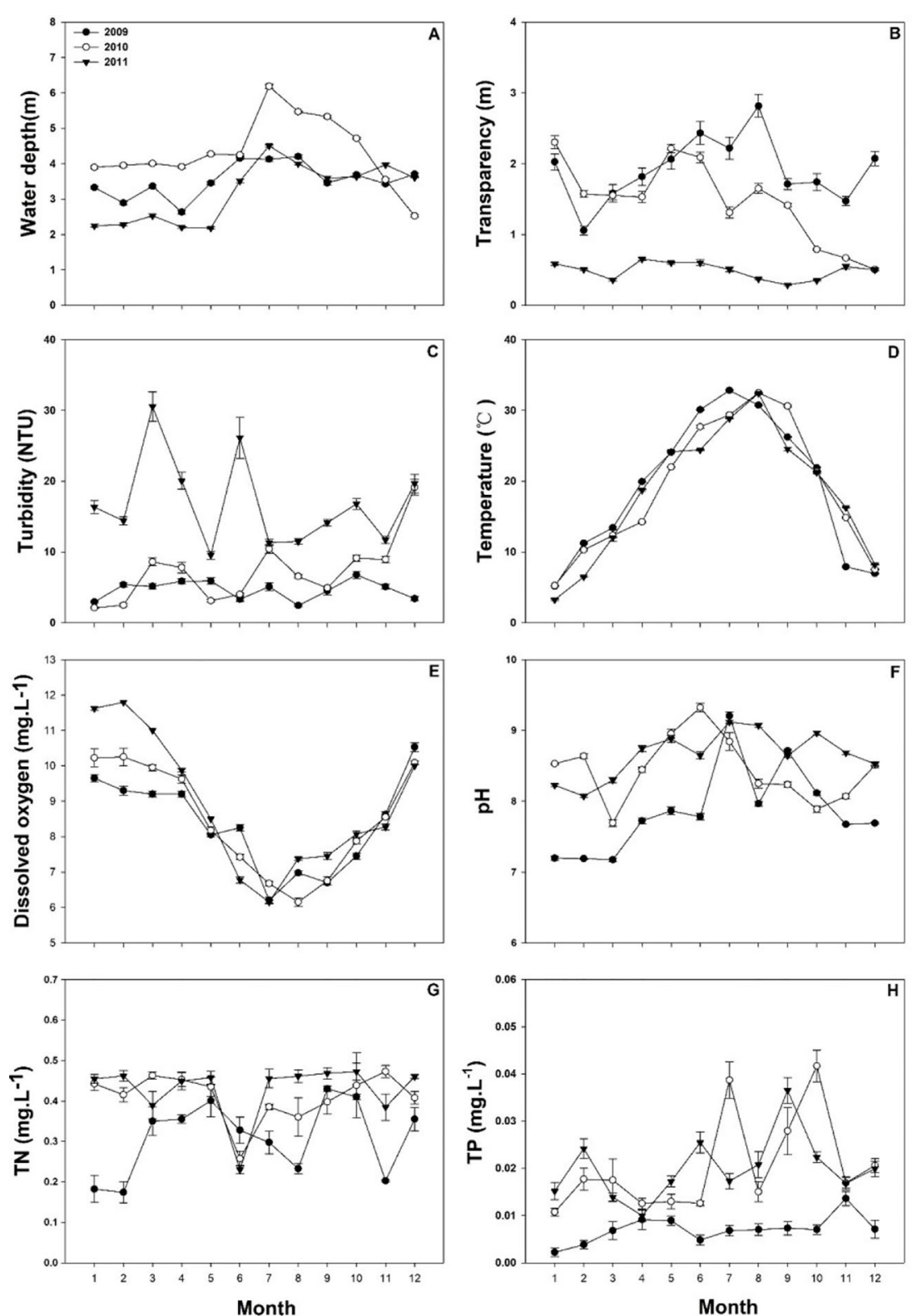

FIGURE 5 | The water parameters of Lake Liangzi. (A) water depth, (B) transparency, (TN), (H) total phosphorus (TP).

\section{Redundancy Analysis (RDA) of Submerged Macrophyte Communities and Water Environmental Cactors}

The eight environmental factors cumulatively accounted for $41.17 \%$ of the species change information in the two axes. A Monte Carlo displacement test showed that the eight environmental factors were significant $(P=0.002)$, indicating that the transparency (which explained $36.8 \%$ of the variability with a correlation of $72.05 \%$ with the presence of submerged macrophytes), turbidity (which explained $11.9 \%$ of the variability), and water depth (which explained $8.3 \%$ of the variability) were factors affecting the structure of the submerged plant communities and were, therefore, key environmental water factors.

The gradient of the first axis from left to right shows that as the transparency increases and turbidity decreases, and the submerged macrophytes (except $P$. crispus) are distributed in the areas of high transparency (i.e., the positive direction of the first axis) (Figure 6). P. maackianus was related to the first axis and significantly positively correlated with transparency $(P<0.001)$; dissolved oxygen is significantly related to the second axis and negatively correlated with temperature $(P<0.001)$ (Figure 6). 


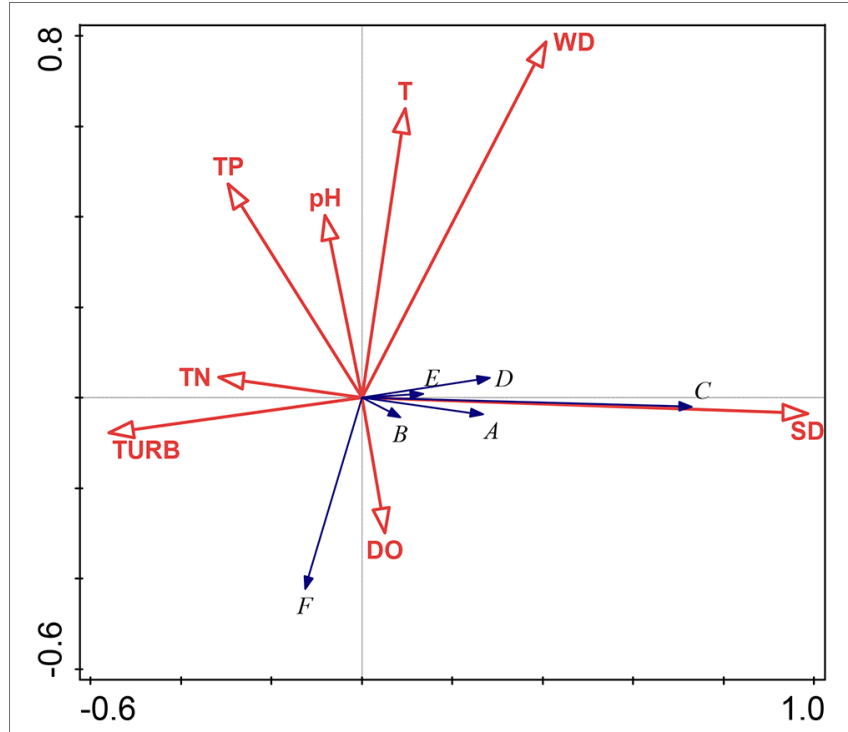

FIGURE 6 | Redundancy analysis ordination diagram of the submerged plant and environmental factors. Species codes: A, Myriophyllum spicatum; B, Vallisneria spiralis; C, Potamogeton maackianus A. Bennett; D, Ceratophyllum demersum; E, Hydrilla verticillata; F, Potamogeton crispus. Environmental codes: DO, Dissolved oxygen; pH, pH of water; SD; Transparency; T, Temperature; TN, Total nitrogen; TP, Total phosphorus; TURB, Turbidity; WD, Water depth.

\section{DISCUSSION}

\section{Dynamic Changes in the Submerged Plant Communities}

In shallow lake ecosystems, the water level is the main factor affecting aquatic plant biomass (Wallsten and Forsgren, 1989; Zhang et al., 2016), and the natural water level is a dynamic factor (Rea and Ganf, 1994). High water levels caused by extreme flooding are known to reduce the diversity of aquatic plant species (Jackson, 1984; Arias et al., 2018). For example, flooding increased the water level and decreased diversity and biomass of the aquatic vegetation; the most serious effect observed was in submerged plants in Poyang Lake in China (Cui et al., 2000). In our survey, after the flood in 2010, the total number of species in Lake Liangzi decreased from ten species in 2009 to five in 2011, and the average number of species per site decreased from $1.38 \pm 0.03$ per $\mathrm{m}^{2}$ in 2009 to $0.5 \pm 0.017$ per $\mathrm{m}^{2}$ in 2011. The diversity and biomass of submerged plants were all significantly decreased by flooding in 2010 . Those decreases were mainly due to a medium-term $3 \mathrm{~m}$ rise in the water level within several days, and this reached more than $6 \mathrm{~m}$ for a brief time; consequently, such an increased water depth significantly inhibited the growth of many submerged plants (Wang et al., 2016b). In addition, there was a negative relationship between submerged macrophyte dominance and the long-term annual duration of inundation (Van Geest et al., 2003). Thus, the long duration of higher water levels (a greater than $4 \mathrm{~m}$ increase in water level that persisted for four months from July to October) caused by the flooding of Lake Liangzi in 2010 resulted in the dying-off of a large number of the submerged plants, and the dry biomass thus decreased significantly. On the other hand, a certain period of time is required for plants to adapt to different water levels (Bornette and Puijalon, 2011). The lack of significant differences in the number of species in July and August of 2009 and 2010 suggests that the submerged plants in Lake Liangzi had some tolerance for the short-term changes in water levels during flooding.

The RDA analysis showed that water transparency, turbidity, and water depth were the key water environmental factors affecting the submerged plants (Figure 6). The increase in water level leads to reduced light availability in shallow lakes, thereby limiting the growth of submerged plants (Van Geest et al., 2007). Decreasing water transparency significantly decreased the communities in terms of biomass, and it also decreased the submerged plants species' richness (Vestergaard and SandJensen, 2000; Wang et al., 2016b). The key factor determining whether submerged plants can regenerate is the underwater light conditions during the germination period of the plants' vegetative propagules ( $\mathrm{Lu}$ et al., 2012). Weak underwater light intensity prevents germination, thus the number of species decreases (Madsen et al., 2001). Thus, when sediment is disturbed by flooding, it causes the water transparency to decrease and the turbidity to increase, and this lack of underwater light affects the growth and reproduction of the submerged plants. In the present study, the water turbidity increased, the transparency of the water decreased after flooding, and these factors inhibited the growth and regeneration of submerged plants.

$P$. maackianus is the dominant species in the submerged vegetation of many lakes in the middle and lower reaches of the Yangtze River (Li et al., 2004). It is a constructive species in submerged plant communities, and the distribution area of the P. maackianus community once accounted for $50 \%$ of the total area of submerged plants in Lake Liangzi (Zhan et al., 2001). We also found that it was the dominant species in Lake Liangzi (dominance > 60\%) in 2009 and 2010. However, after the 2010 flooding, the dominant species was P. crispus in February, March, April, May, November, and December of 2011. P. maackianus was the dominant species only from June to October of 2011 (Figure 4), which was mainly because the summer buds (dormant buds) of P. crispus germinate in the autumn and then grow over the winter. It was thus able to become the dominant species from February to May in 2011. Although P. maackianus can grow in winter, the flooding caused turbidity to increase, water transparency to decrease, and light intensity to weaken, resulting in the $P$. maackianus gradually dying. The tolerance of the summer buds (dormant buds) of $P$. crispus is strong. For example, higher water turbidity (90NTU) had no effect on the germination rate and growth of summer buds (Li, 2012), whereas four meters of water depth significantly affected the growth of $P$. maackianus (Zhu et al., 2012; Li et al., 2013), In addition, previous studies have found that $P$. crispus can successfully recover, while it has been difficult to successfully restore $P$. maackianus because P. maackianus are K-selected plants (Qiu et al., 2001b; Zhu et al., 2012; Fu et al., 2018b) and P. crispus are r-selected plants (Pierce et al., 2012). 


\section{Dynamic Changes in the Water Environmental Factors}

The submerged macrophytes improve their own light climate by enhancing the water transparency (Van den Berg et al., 1998). There is a significant positive relationship between water transparency and the maximum colonization depth of aquatic plants (Canfield et al., 1985; Sondergaard et al., 2013). These two parameters of the water before the flooding in 2009 were stable due to the high species numbers and biomass of submerged vegetation. Floods have an important effect on water clarity (Xu et al., 2018), and extreme water levels may cause shifts between the turbid and the clear, and the macrophyte-dominated state may change to a without-vegetation turbid state (Coops et al., 2003; Scheffer and Carpenter, 2003). The flooding of Lake Liangzi in 2010 caused the turbidity to increase and, consequently, the water transparency to decrease. In addition, large areas of aquatic vegetation disappeared in Lake Liangzi after the flood. Submerged plants were only found at five monitoring points and one monitoring point in September and October 2011.

Nutrient input, mainly of $\mathrm{N}$ and $\mathrm{P}$, is derived from the eutrophic main channels during floods (Van den Brink et al., 1994). A large amount of suspended sediment and, consequently, a higher concentration of nutrients into Lake Liangzi is caused by flooding that increases the content of nitrogen and phosphorus in water. During the growth phase, the water column is depleted in nutrient concentrations, whereas, during the decay period, there is a significant increase in water column nutrients (Shilla et al., 2006). Furthermore, the decomposition of submerged macrophytes is influenced by several factors, though water temperature has been cited as an important environmental factor (Carpenter

\section{REFERENCES}

Alfieri, L., Dottori, F., Betts, R., Salamon, P., and Feyen, L. (2018). Multi-model projections of river flood risk in Europe under global warming. Climate 6 (1), 6. doi: 10.3390/cli6010016

Andersson, B. (2001). Macrophyte development and habitat characteristics in Sweden's large lakes. Ambio 30 (8), 503-513. doi: 10.1639/0044-7447(2001)030[0503:mdahci]2.0.co;2

Arias, M. E., Wittmann, F., Parolin, P., Murray-Hudson, M., and Cochrane, T. A. (2018). Interactions between flooding and upland disturbance drives species diversity in large river floodplains. Hydrobiologia 814 (1), 5-17. doi: 10.1007/ s10750-016-2664-3

Armstrong, W., Brändle, R., and Jackson, M. B. (1994). Mechanisms of flood tolerance in plants. Acta Botanica Neerlandica 43 (4), 307-358. doi: 10.1111/ j.1438-8677.1994.tb00756.x

Bornette, G., and Puijalon, S. (2011). Response of aquatic plants to abiotic factors: a review. Aquat. Sci. 73 (1), 1-14. doi: 10.1007/s00027-010-0162-7

Cai, W., Wang, G., Santoso, A., McPhaden, M. J., Wu, L., Jin, F.-F., et al. (2015). Increased frequency of extreme La Niña events under greenhouse warming. Nat. Climate Change 5 (2), 132. doi: 10.1038/NCLIMATE2492

Canfield, D., Langeland, K., Linda, S., and Haller, W. (1985). Relations between water transparency and maximum depth of macrophyte colonization in lakes. J. Aquat. Plant Manage. 23 (1), 25-28.

Carpenter, S. R. (2008). Phosphorus control is critical to mitigating eutrophication. Proc. Natl. Acad. Sci. United States America 105 (32), 11039-11040. doi: 10.1073/pnas.0806112105

Carpenter, S. R., and Adams, M. S. (1979). Effects of nutrients and temperature on decomposition of Myriophyllum spicatum L. in a hard-water eutrophic lake. Limnology Oceanography 24 (3), 520-528. doi: 10.4319/lo.1979.24.3.0520 and Adams, 1979; Carvalho et al., 2005). After the flooding in Lake Liangzi it was still a hot season, the higher temperature accelerating the decomposition of dead aquatic plants caused by the flood in 2010. Higher turbidity, higher total nitrogen and phosphorus, and lower transparency after the flooding in 2010 all contributed to the downward trend in water quality.

\section{CONCLUSION}

The serious flooding of 2010 in Lake Liangzi decreased species diversity and the biomass of submerged aquatic plants and resulted in declining water quality. P. maackianus was the dominant submerged species during the whole year before flooding, while this dominant position weakened after the flooding. The results suggest that heavy flooding may change the submerged community succession.

\section{DATA AVAILABILITY STATEMENT}

All datasets generated for this study are included in the manuscript and the supplementary files.

\section{AUTHOR CONTRIBUTIONS}

CL designed the study. LW, YH, and SF performed the field monitoring. LW, YH and HY analyzed the data. LW drafted the manuscript with the assistance of CL. All the co-authors commented on and approved the final manuscript.

Carvalho, P., Thomaz, S. M., and Bini, L. M. (2005). Effects of temperature on decomposition of a potential nuisance species: the submerged aquatic macrophyte Egeria najas planchom (Hydrocharitaceae). Braz. J. Biol. 65, 51-60. doi: 10.1590/S1519-69842005000100008

Casanova, M. T., and Brock, M. A. (2000). How do depth, duration and frequency of flooding influence the establishment of wetland plant communities? Plant Ecol. 147 (2), 237-250. doi: 10.1023/A:1009875226637

Castello, L., and Macedo, M. N. (2016). Large-scale degradation of Amazonian freshwater ecosystems. Global Change Biol. 22 (3), 990-1007. doi: 10.1111/ gcb.13173

Chaparro, G., Fontanarrosa, M. S., Schiaffino, M. R., de Tezanos Pinto, P., and O'Farrell, I. (2014). Seasonal-dependence in the responses of biological communities to flood pulses in warm temperate floodplain lakes: implications for the "alternative stable states" model. Aquat. Sci. 76 (4), 579-594. doi: 10.1007/s00027-014-0356-5

Chen, H. (1980). Structure and dynamics of macrophyte communities in lake DongHu,Wuhan. Oceanologia Et Limnologia Sin. 11 (3), 275-284.

Coops, H., and Doef, R. W. (1996). Submerged vegetation development in two shallow, eutrophic lakes. Hydrobiologia 340 (1-3), 115-120. doi: 10.1007/ bf00012742

Coops, H., Beklioglu, M., and Crisman, T. L. (2003). The role of water-level fluctuations in shallow lake ecosystems - workshop conclusions. Hydrobiologia 506 (1-3), 23-27. doi: 10.1023/b:hydr.0000008595.14393.77

Cui, X. H., Yang, Z., LI, W., and Chen, J. K. (2000). The effect of catastrophic flood on biomass and density of three dominant aquatic plant species in the Poyang Lake. Acta hydrobiologica Sin. 24 (4), 322-325. doi: 10.3321/j. issn:1000-3207.2000.04.004

Cui, N., Wu, J., Dai, Y., Li, Z., and Cheng, S. (2017). Influence of nitrogen loading and flooding on seedling emergence and recruitment from a seed bank in 
Chaohu Lake Basin, China. Environ. Sci. Pollution Res. 24 (28), 22688-22697. doi: 10.1007/s11356-017-9926-0

Deegan, B. M., White, S. D., and Ganf, G. G. (2007). The influence of water level fluctuations on the growth of four emergent macrophyte species. Aquat. Bot. 86 (4), 309-315. doi: 10.1016/j.aquabot.2006.11.006

Dorn, N. J., and Cook, M. I. (2015). Hydrological disturbance diminishes predator control in wetlands. Ecology 96 (11), 2984-2993. doi: 10.1890/14-1505.1

Drew, M. C. (1997). Oxygen deficiency and root metabolism: injury and acclimation under hypoxia and anoxia. Annu. Rev. Plant Biol. 48 (1), 223-250. doi: 10.1890/14-1505.1

Fowler, A., and Hennessy, K. (1995). Potential impacts of global warming on the frequency and magnitude of heavy precipitation. Natural Hazards 11 (3), 283303. doi: 10.1007/BF00613411

Fu, H., Yuan, G., Lou, Q., Dai, T., Xu, J., Cao, T., et al. (2018a). Functional traits mediated cascading effects of water depth and light availability on temporal stability of a macrophyte species. Ecol. Indic. 89, 168-174. doi: 10.1016/j. ecolind.2018.02.010

Fu, H., Yuan, G. X., Lou, Q., Dai, T. T., Xu, J., Cao, T., et al. (2018b). Functional traits mediated cascading effects of water depth and light availability on temporal stability of a macrophyte species. Ecol. Indic. 89, 168-174. doi: 10.1016/j.ecolind.2018.02.010

Gafny, S., and Gasith, A. (1999). Spatially and temporally sporadic appearance of macrophytes in the littoral zone of Lake Kinneret, Israel: taking advantage of a window of opportunity. Aquat. Bot. 62 (4), 249-267. doi: 10.1016/ S0304-3770(98)00097-7

Hölzel, N., and Otte, A. (2004). Assessing soil seed bank persistence in floodmeadows: The search for reliable traits. J. Vegetation Sci. 15 (1), 93-100. doi: 10.1658/1100-9233(2004)015[0093:ASSBPI]2.0.CO;2

Han, Y.-Q., Wang, L.-G., You, W.-H., Yu, H.-H., Xiao, K.-Y., and Wu, Z.-H. (2018). Flooding interacting with clonal fragmentation affects the survival and growth of a key floodplain submerged macrophyte. Hydrobiologia 806 (1), 67-75. doi: 10.1007/s10750-017-3356-3

Heikkinen, R., Leikola, N., Fronzek, S., Lampinen, R., and Toivonen, H. (2009). Predicting distribution patterns and recent northward range shift of an invasive aquatic plant: Elodea canadensis in Europe. BioRisk 2, 1. doi: 10.3897/ biorisk.2.4

Hirsch, R. M., and Archfield, S. A. (2015). Flood trends: Not higher but more often. Nat. Climate Change 5 (3), 198-199. doi: 10.1038/nclimate2551

Ishii, J., and Kadono, Y. (2004). Sexual reproduction under fluctuating water levels in an amphibious plant Schoenoplectus lineolatus (Cyperaceae): a waiting strategy? Limnology 5 (1), 1-6. doi: 10.1007/s10201-003-0108-Z

Jackson, M. B. (1984). Effects of flooding on growth and metabolism of herbaceous plants. Flooding Plant Growth 47-128. doi: 10.1016/B978-0-12-424120-6.50008-0

Jeppesen, E., Jensen, J. P., Søndergaard, M., Lauridsen, T., Pedersen, L. J., and Jensen, L. (1997). Top-down control in freshwater lakes: the role of nutrient state, submerged macrophytes and water depth. Hydrobiologia 342-343 (1), 151-164. doi: 10.1023/A:1017046130329

Jeppesen, E., Søndergaard, M., Søndergaard, M., and Christoffersen, K. (1998). The structuring role of submerged macrophytes in lakes. Ecol. Stud. 131. doi: 10.1007/978-1-4612-0695-8

Jeppesen, E., Brucet, S., Naselli-Flores, L., Papastergiadou, E., Stefanidis, K., Noges, T., et al. (2015). Ecological impacts of global warming and water abstraction on lakes and reservoirs due to changes in water level and related changes in salinity. Hydrobiologia 750 (1), 201-227. doi: 10.1007/s10750-014-2169-x

Johansson, M., and Nilsson, C. (2002). Responses of riparian plants to flooding in free-flowing and regulated boreal rivers: an experimental study. J. Appl. Ecol. 39 (6), 971-986. doi: 10.1046/j.1365-2664.2002.00770.x

Junk, W. J., and Robertson, B. A. (1997). Aquatic invertebrates. The Central Amazon Floodplain. Ecology of a Pulsing System. (Springer-Verlag, Berlin), pp 279-298.

Keitel, J., Zak, D., and Hupfer, M. (2016). Water level fluctuations in a tropical reservoir: the impact of sediment drying, aquatic macrophyte dieback, and oxygen availability on phosphorus mobilization. Environ. Sci. Pollution Res. 23 (7), 6883-6894. doi: 10.1007/s11356-015-5915-3

Lehmann, J., Coumou, D., and Frieler, K. (2015). Increased record-breaking precipitation events under global warming. Climatic Change 132 (4), 501-515. doi: 10.1007/s10584-015-1434-y

Lemke, M., Casper, A. F., Van Middlesworth, T. D., Hagy, H. M., Walk, J., Blodgett, D., et al. (2014). Ecological response of floodplain restoration to flooding disturbance: a comparison of the effects of heavy and light flooding. In World Environmental and Water Resources Congress 2014. pp. 1120-1127.

Lenssen, J. P., Van Kleunen, M., Fischer, M., and De Kroon, H. (2004). Local adaptation of the clonal plant Ranunculus reptans to flooding along a small-scale gradient. J. Ecol. 92 (4), 696-706. doi: 10.1111/j.0022-0477.2004. 00895.X

Li, W., Xia, L. Q., Li, J. Q., and Wang, G. X. (2004). Genetic diversity of Potamogeton maackianus in the Yangtze River. Aquat. Bot. 80 (4), 227-240. doi: 10.1016/j. aquabot.2004.07.003

Li, W., Cao, T., Ni, L., Zhang, X., Zhu, G., and Xie, P. (2013). Effects of water depth on carbon, nitrogen and phosphorus stoichiometry of five submersed macrophytes in an in situ experiment. Ecol. Eng. 61, 358-365. doi: 10.1016/j. ecoleng.2013.09.028

Li, X., Zhang, Q., Xu, C.-Y., and Ye, X. (2015). The changing patterns of floods in Poyang Lake, China: characteristics and explanations. Natural Hazards 76 (1), 651-666. doi: 10.1007/s11069-014-1509-5

$\mathrm{Li}, \mathrm{Q}$. (2012). Influence of silts on the growth, reproduction and chlorophyll fluorescence of Potamogeton crispus in turbid water. Russian J. Ecol. 43 (2), 122-130. doi: 10.1134/S1067413612020105

Lu, J., Wang, H. B., Pan, M., Xia, J., Xing, W., and Liu, G. H. (2012). Using sediment seed banks and historical vegetation change data to develop restoration criteria for a eutrophic lake in China. Ecol. Eng. 39, 95-103. doi: 10.1016/j. ecoleng.2011.11.006

Madsen, J. D., Chambers, P. A., James, W. F., Koch, E. W., and Westlake, D. F. (2001). The interaction between water movement, sediment dynamics and submersed macrophytes. Hydrobiologia 444 (1-3), 71-84. doi: 10.1023/a:1017520800568

MaGuarran, A. (1988). Ecological diversity and its measurement (Princeton University Press).

Maltchik, L., De Oliveira, R., Rolon, A. S., and Stenert, C. (2005). Diversity and stability of aquatic macrophyte community in three shallow lakes associated to a floodplain system in the south of Brazil. Interciencia 30 (3), 166-170.

Marklund, O., Sandsten, H., Hansson, L. A., and Blindow, I. (2002). Effects of waterfowl and fish on submerged vegetation and macroinvertebrates. Freshwater Biol. 47 (11), 2049-2059. doi: 10.1046/j.1365-2427.2002.00949.x

Meerhoff, M., Mazzeo, N., Moss, B., and Rodríguez-Gallego, L. (2003). The structuring role of free-floating versus submerged plants in a subtropical shallow lake. Aquat. Ecol. 37 (4), 377-391. doi: 10.1023/B:AECO.000000704 $1.57843 .0 \mathrm{~b}$

Middelboe, A. L., and Markager, S. (1997). Depth limits and minimum light requirements of freshwater macrophytes. Freshwater Biol. 37 (3), 553-568. doi: 10.1046/j.1365-2427.1997.00183.x

Newman, S., and Reddy, K. (1992). Sediment resuspension effects on alkaline phosphatase activity. Hydrobiologia 245 (2), 75-86. doi: 10.1007/BF00764767

O’Reilly, C. M., Sharma, S., Gray, D. K., Hampton, S. E., Read, J. S., Rowley, R. J., et al. (2015). Rapid and highly variable warming of lake surface waters around the globe. Geophysical Res. Lett. 42 (24), 10,773-710,781. doi: 10.1002/2015GL066235

Phillips, G., Willby, N., and Moss, B. (2016). Submerged macrophyte decline in shallow lakes: what have we learnt in the last forty years? Aquat. Bot. 135, 37-45. doi: 10.1016/j.aquabot.2016.04.004

Pierce, S., Brusa, G., Sartori, M., and Cerabolini, B. E. (2012). Combined use of leaf size and economics traits allows direct comparison of hydrophyte and terrestrial herbaceous adaptive strategies. Ann. Bot. 109 (5), 1047-1053. doi: $10.1093 / \mathrm{aob} / \mathrm{mcs} 021$

Qiu, D., Wu, Z., Liu, B., Deng, J., Fu, G., and He, F. (2001a). The restoration of aquatic macrophytes for improving water quality in a hypertrophic shallow lake in Hubei Province, China. Ecol. Eng. 18 (2), 147-156. doi: 10.1016/ S0925-8574(01)00074-X

Qiu, D. R., Wu, Z. B., Liu, B. Y., Deng, J. Q., Fu, G. P., and He, F. (2001b). The restoration of aquatic macrophytes for improving water quality in a hypertrophic shallow lake in Hubei Province, China. Ecol. Eng. 18 (2), 147-156. doi: 10.1016/s0925-8574(01)00074-x

Rea, N., and Ganf, G. G. (1994). How emergent plants experience water regime in a Mediterranean-type wetland. Aquat. Bot. 49 (2-3), 117-136. doi: 10.1016/0304-3770(94)90033-7

Søndergaard, M., Kristensen, P., and Jeppesen, E. (1992). Phosphorus release from resuspended sediment in the shallow and wind-exposed Lake Arresø, Denmark. Hydrobiologia 228 (1), 91-99. doi: 10.1007/BF00006480 
Sand-Jensen, K., Pedersen, N. L., Thorsgaard, I., Moeslund, B., Borum, J., and Brodersen, K. P. (2008). 100 years of vegetation decline and recovery in Lake Fure, Denmark. J. Ecol. 96 (2), 260-271. doi: 10.1111/j.1365-2745.2007.01339.x

Scheffer, M., and Carpenter, S. R. (2003). Catastrophic regime shifts in ecosystems: linking theory to observation. Trends In Ecol. Evol. 18 (12), 648-656. doi: 10.1016/j.tree.2003.09.002

Scheffer, M., Redelijkheid, M. R. D., and Noppert, F. (1992). Distribution and dynamics of submerged vegetation in a chain of shallow eutrophic lakes. Aquat. Bot. 42 (3), 199-216. doi: 10.1016/0304-3770(92)90022-B

Schneider, B., Cunha, E. R., Marchese, M., and Thomaz, S. M. (2018). Associations between macrophyte life forms and environmental and morphometric factors in a large sub-tropical floodplain. Front. In Plant Sci. 9 (195). doi: 10.3389/ fpls.2018.00195

Shilla, D., Asaeda, T., Fujino, T., and Sanderson, B. (2006). Decomposition of dominant submerged macrophytes: implications for nutrient release in Myall Lake, NSW, Australia. Wetlands Ecol. Manage. 14 (5), 427-433. doi: 10.1007/ s11273-006-6294-9

Short, F. T., Kosten, S., Morgan, P. A., Malone, S., and Moore, G. E. (2016). Impacts of climate change on submerged and emergent wetland plants. Aquat. Bot. 135, 3-17. doi: 10.1016/j.aquabot.2016.06.006

Solheim, A. L., Austnes, K., Eriksen, T. E., Seifert, I., and Holen, S. (2010). Climate change impacts on water quality and biodiversity. Background Rep. EEA Eur. Environ. State Outlook Rep.

Sondergaard, M., Phillips, G., Hellsten, S., Kolada, A., Ecke, F., Maemets, H., et al. (2013). Maximum growing depth of submerged macrophytes in European lakes. Hydrobiologia 704 (1), 165-177. doi: 10.1007/s10750-012-1389-1

Sponberg, A. F., and Lodge, D. M. (2005). Seasonal belowground herbivory and a density refuge from waterfowl herbivory for Vallisneria americana. Ecology 86 (8), 2127-2134. doi: 10.1890/04-1335

Strand, J. A., and Weisner, S. E. B. (2001). Morphological plastic responses to water depth and wave exposure in an aquatic plant (Myriophyllum spicatum). J. Ecol. 89 (2), 166-175. doi: 10.1046/j.1365-2745.2001.00530.x

Tamire, G., and Mengistou, S. (2013). Macrophyte species composition, distribution and diversity in relation to some physicochemical factors in the littoral zone of Lake Ziway, Ethiopia. Afr. J. Ecol. 51 (1), 66-77. doi: 10.1111/ aje. 12007

Tockner, K., Baumgartner, C., Schiemer, F., and Ward, J. (2000). Biodiversity of a Danubian floodplain: structural, functional and compositional aspects. Biodiversity In wetlands: assessment Funct. Conserv. 1, 141-159.

Tong, Y., Liang, T., Wang, L., and Li, K. (2017). Simulation on phosphorus release characteristics of Poyang Lake sediments under variable water levels and velocities. J. Geographical Sci. 27 (6), 697-710. doi: 10.1007/s11442-017-1401-9

Trenberth, K. E. (2011). Changes in precipitation with climate change. Climate Res. 47 (1-2), 123-138. doi: 10.3354/cr00953

Van den Berg, M. S., Coops, H., Meijer, M.-L., Scheffer, M., and Simons, J. (1998). "Clear water associated with a dense Chara vegetation in the shallow and turbid Lake Veluwemeer, the Netherlands," in The structuring role of submerged macrophytes in lakes. (New York: Springer-Verlag), 339-352.

Van den Brink, F. W. B., Van Katwijk, M. M., and Van der Velde, G. (1994). Impact of hydrology on phyto- and zooplankton community composition in floodplain lakes along the Lower Rhine and Meuse. J. Plankton Res. 16 (4), 351-373. doi: 10.1093/plankt/16.4.351

Van Geest, G., Roozen, F., Coops, H., Roijackers, R., Buijse, A., Peeters, E., et al. (2003). Vegetation abundance in lowland flood plan lakes determined by surface area, age and connectivity. Freshwater Biol. 48 (3), 440-454. doi: 10.1046/j.1365-2427.2003.01022.x

Van Geest, G., Coops, H., Roijackers, R., Buijse, A., and Scheffer, M. (2005). Succession of aquatic vegetation driven by reduced waterlevel fluctuations in floodplain lakes. J. Appl. Ecol. 42 (2), 251-260. doi: 10.1111/j.1365-2664.2005.00995.x

Van Geest, G. J., Coops, H., Scheffer, M., and van Nes, E. H. (2007). Long transients near the ghost of a stable state in eutrophic shallow lakes with fluctuating water levels. Ecosystems 10 (1), 37-47. doi: 10.1007/s10021-006-9000-0

Vartapetian, B. B., and Jackson, M. B. (1997). Plant adaptations to anaerobic stress. Ann. Bot. 79 (suppl_1), 3-20. doi: 0.1093/oxfordjournals.aob. a010303

Verhofstad, M. J. J. M., Alirangues Núñez, M. M., Reichman, E. P., van Donk, E., Lamers, L. P. M., and Bakker, E. S. (2017). Mass development of monospecific submerged macrophyte vegetation after the restoration of shallow lakes: roles of light, sediment nutrient levels, and propagule density. Aquat. Bot. 141, 29-38. doi: 10.1016/j.aquabot.2017.04.004

Vermaat, J. E., Santamaria, L., and Roos, P. J. (2000). Water flow across and sediment trapping in submerged macrophyte beds of contrasting growth form. ArchivFur Hydrobiologie 148 (4), 549-562. doi: 10.1127/archiv-hydrobiol/148/2000/549

Vestergaard, O., and Sand-Jensen, K. (2000). Aquatic macrophyte richness in Danish lakes in relation to alkalinity, transparency, and lake area. Can. J. Fisheries Aquat. Sci. 57 (10), 2022-2031. doi: 10.1139/f00-156

Wallsten, M., and Forsgren, P. (1989). The effects of increased water level on aquatic macrophytes. J. Aquat. Plant Manage. 27, 32-37.

Wang, S., and Yuan, X. (2018). Extending seasonal predictability of Yangtze River summer floods. Hydrology Earth System Sci. 22 (8), 4201-4211. doi: 10.5194/ hess-22-4201-2018

Wang, M.-Z., Liu, Z.-Y., Luo, F.-L., Lei, G.-C., and Li, H.-L. (2016a). Do amplitudes of water level fluctuations affect the growth and community structure of submerged macrophytes? PloS One 11 (1), e0146528. doi: 10.1371/journal. pone. 0146528

Wang, P., Zhang, Q., Xu, Y. S., and Yu, F. H. (2016b). Effects of water level fluctuation on the growth of submerged macrophyte communities. Flora 223, 83-89. doi: 10.1016/j.flora.2016.05.005

Wantzen, K. M., Rothhaupt, K.-O., Mörtl, M., Cantonati, M., László, G., and Fischer, P. (2008). Ecological effects of water-level fluctuations in lakes: an urgent issue. Hydrobiologia (613), 1-4.

Watts, G., Battarbee, R. W., Bloomfield, J. P., Crossman, J., Daccache, A., Durance, I., et al. (2015). Climate change and water in the UK-past changes and future prospects. Prog. In Phys. Geography 39 (1), 6-28.

Wetzel, R. G. (2001). Limnology: lake and river ecosystems. Eos Trans. Am. Geophysical Union 21 (2), 1-9. doi: 10.1046/j.1529-8817.2001.37602.x

Wilcox, D. A., and Meeker, J. E. (1991). Disturbance effects on aquatic vegetation in regulated and unregulated lakes in northern Minnesota. Can. J. Bot. 69 (7), 1542-1551. doi: 10.1139/b91-198

Xu, X., Huang, X. L., Zhang, Y. L., and Yu, D. (2018). Long-Term changes in water clarity in Lake Liangzi determined by remote sensing. Remote Sens. 10 (9). doi: 10.3390/rs10091441

Ye, B., Chu, Z., Wu, A., Hou, Z., and Wang, S. (2018). Optimum water depth ranges of dominant submersed macrophytes in a natural freshwater lake. PloS One 13 (3), e0193176.

Yu, J., Liu, Z., He, H., Zhen, W., Guan, B., Chen, F., et al. (2016). Submerged macrophytes facilitate dominance of omnivorous fish in a subtropical shallow lake: implications for lake restoration. Hydrobiologia 775 (1), 97-107. doi: 10.1007/s10750-016-2717-7

Zhan, C. W., Yu, D., Liu, C. H., Wu, Z. H., and Li, Z. Q. (2001). The Community ecology of aquatic plant in the water-land ecotone of Liangzi Lake. Acta Phytoecologica Sin. 5, 573-580. doi: 10.3321/j.issn:1005-264X.2001.05.011

Zhang, Y., Liu, X., Qin, B., Shi, K., Deng, J., and Zhou, Y. (2016). Aquatic vegetation in response to increased eutrophication and degraded light climate in Eastern Lake Taihu: Implications for lake ecological restoration. Sci. Rep. 6, 23867. doi: 10.1038/srep23867

Zhu, G., Li, W., Zhang, M., Ni, L., and Wang, S. (2012). Adaptation of submerged macrophytes to both water depth and flood intensity as revealed by their mechanical resistance. Hydrobiologia 696 (1), 77-93. doi: 10.1007/ s10750-012-1185-y

Conflict of Interest: The authors declare that the research was conducted in the absence of any commercial or financial relationships that could be construed as a potential conflict of interest.

The handling editor is currently organizing a Research Topic with one of the authors CL, and confirms the absence of any other collaboration.

Copyright (c) 2019 Wang, Han, Yu, Fan and Liu. This is an open-access article distributed under the terms of the Creative Commons Attribution License (CC BY). The use, distribution or reproduction in other forums is permitted, provided the original author(s) and the copyright owner(s) are credited and that the original publication in this journal is cited, in accordance with accepted academic practice. No use, distribution or reproduction is permitted which does not comply with these terms. 